Summer 8-1-2020

\title{
When Freedom of Speech Comes at a Cost: A Case Study of E.S.
}

\section{v. Austria}

Rachael Taylor

Indiana University Maurer School of Law, rachtayl@iu.edu

Follow this and additional works at: https://www.repository.law.indiana.edu/ijgls

Part of the Comparative and Foreign Law Commons, Courts Commons, Criminal Law Commons, Human Rights Law Commons, and the Religion Law Commons

\section{Recommended Citation}

Taylor, Rachael (2020) "When Freedom of Speech Comes at a Cost: A Case Study of E.S. v. Austria," Indiana Journal of Global Legal Studies: Vol. 27 : Iss. 2 , Article 11.

Available at: https://www.repository.law.indiana.edu/ijgls/vol27/iss2/11

This Note is brought to you for free and open access by the Law School Journals at Digital Repository @ Maurer Law. It has been accepted for inclusion in Indiana Journal of Global Legal Studies by an authorized editor of Digital Repository @ Maurer Law. For more information, please contactrvaughan@indiana.edu.

\section{$\Psi$}

JEROME HALL LAW LIBRARY

INDIANA UNIVERSITY

Maurer School of Law
Blooming ton 


\title{
When Freedom of Speech Comes at a Cost: A Case Study of E.S. v. Austria
}

\author{
RACHAEL TAYLOR ${ }^{*}$
}

\begin{abstract}
In the fall of 2018, the European Court of Human Rights (ECtHR) issued a decision upholding the criminal conviction of an Austrian national (E.S.) in violation of Austria's Criminal Code against the disparagement of religious doctrines. Her initial conviction in the Austrian court was based on statements she made about the Prophet Muhammad while teaching a series of seminars entitled "Basic Information on Islam." In upholding her conviction, the ECtHR found that there had been no violation of the Austrian's right to freedom of expression under Article 10 of the European Convention for the Protection of Human Rights (Convention), and therefore Austria's conviction was valid and did not impermissibly infringe on her right to freedom of expression. This case adds yet another dimension to the polarizing debate regarding freedom of expression and the permissible limitations that may be placed upon this freedom. In this article, I argue that this case can be viewed as a turning point in the free expression debate, and perhaps indicates an awareness that such restrictions on speech may be necessary in order to maintain public safety and order.
\end{abstract}

\section{INTRODUCTION}

In October 2018, the ECtHR issued a decision in regard to the freedom of expression under the Convention, upholding criminal sanctions against an Austrian national for statements she made that the Austrian Court held had "disparag[ed]" the Prophet Muhammad. ${ }^{1}$

* J.D. Candidate, 2020, Indiana University Maurer School of Law-Bloomington, IN; B.A. English, B.A. Telecommunications, 2017, Indiana University-Bloomington, IN. Special thanks to my family and friends for always being there for support and creative feedback. Thanks to the editors and journal team for their incredible work in helping get this article ready for publication.

Indiana Journal of Global Legal Studies Vol. 27 \#2 (Spring 2020)

(c) Indiana University Maurer School of Law 
The ruling of this case has been both praised and criticized for its implications on freedom of expression: not only for the countries party to the convention, but for the precedent this decision may have set for other courts internationally experiencing violence due to unregulated speech. While many may feel that this case poses a serious threat to principles of freedom of expression, I argue that such limitations may be necessary in our current social climate as a means to address the rising incidence of hate crimes and violence around the world.

First, I provide a background of this case in order to highlight some of the key aspects of the Court's reasoning behind its holding. Then I address some of the main criticisms of this ruling and indicate some of the shortcomings of these popular dissenting arguments against the ECtHR's holding. Last, I discuss some of the prevailing theories of free expression and how this decision comports and departs from these traditional views. This note shows that cases regarding freedom of expression can serve an important preventative role, and that while limitations on freedom of expression may be undesirable, these limitations may be necessary.

\section{THE CASE OF E.S. V. AUSTRIA}

This case against the Republic of Austria came before the European Court of Human Rights in 2018 under Article 34 of the Convention. ${ }^{2}$ An Austrian national, E.S., claimed that her criminal conviction for disparaging religious doctrines violated her rights to freedom of expression under Article 10 of the Convention. ${ }^{3}$

\section{Regional Court}

The applicant's Austrian criminal conviction arose from statements E.S. made during several seminars she held in January 2008, entitled "Basic Information on Islam," at the right-wing Freedom Party Education Institute in Vienna, Austria.4 The Vienna Regional Court

1. E.S. v. Austria, Eur. Ct. H.R. 1 (2018), https://hudoc.echr.coe.int/eng\#\{ "fulltext":["E.S.\%20v.\%20Austria"],"documentcollectionid2":["JUDGMENTS","DECISION S"],"itemid":["001-187188"]\}.

2. See Convention for the Protection of Human Rights and Fundamental Freedoms As Amended by Protocols Nos. 11 and 14, Council of Europe, art. 34, Nov. 4, 1950, E.T.S. No. 005 ("The Court may receive applications from any person ... claiming to be the victim of a violation by one of the High Contracting Parties of the rights set forth in the Convention or the Protocols thereto.").

3. E.S., Eur. Ct. H.R. at 1; see also id. art. 10.

4. E.S., Eur. Ct. H.R. at 2. 
found the teacher's statements regarding the Prophet Muhammad to be incriminating. For example, in one of the seminars, E.S. stated:

One of the biggest problems we are facing today is that Muhammad is seen as the ideal man, the perfect human, the perfect Muslim. That means that the highest commandment for a male Muslim is to imitate Muhammad, to live his life. This does not happen according to our social standards and laws. Because he was a warlord, he had many women, to put it like this, and liked to do it with children. And according to our standards he was not a perfect human. We have huge problems with that today, that Muslims get into conflict with democracy and our value system. ${ }^{5}$

E.S. went on to make comments about one of the most important Islamic writings, the Sahih Al-Bukhari, stating that "one can be sure that all Muslims [will] recogni[z]e it. And unfortunately, in Al-Bukhari the thing with Aisha [one of Muhammad's wives who was an adolescent at the time of their marriage $]^{6}$ and child sex is written." 7 E.S. also retold a discussion she had with her sister in which her sister informed E.S. that she could "not say it like that! [that Muhammad was a pedophile]." E.S. recounted to the participants her response:

A 56-year-old and a six-year-old? What do you call that? Give me an example? What do we call it, if it is not paedophilia? ... We have heard that so many times. "Those were different times" - it wasn't okay back then, and it's not okay today. Full stop. And it is still happening today. One can never approve something like that. 8

These seminars were publicly advertised and were aimed at young voters as part of a "free education package,"9 and E.S. did not select the participants in the lecture. Unbeknownst to E.S., an undercover journalist participated in the seminars, whose employer ultimately reported the statements to the public prosecutor..$^{10}$ In February of 2010,

\footnotetext{
5. Id. at 3 .

6. Id. at 3-4.

7. Id. at 3 .

8. Id.

9. Id. at 2 .

10. $I d$.
} 
E.S. was "questioned by the police concerning certain statements she had made during the seminars," and charges were later brought against her for inciting hatred, ${ }^{11}$ a crime in Austria pursuant to Article 188 of Austria's Criminal Code. ${ }^{12}$

In response to her charges, E.S. claimed to have based her above statements on historical accounts that one of Muhammad's wives, Aisha, who was six-years-old when they were married, and allegedly nine-years-old when the marriage was consummated.13 Therefore, according to E.S., because these statements were factual, they were immune from sanction. ${ }^{14}$ The Regional Court did not share this view, and although the statements may have had some basis in fact, the Court perceived the statements to be "derogatory value judgments." 15 As E.S. did not present any evidence to support her contention, the Court was unable to conclude that E.S. was actually trying to relay a statement of fact and not espouse a prejudicial judgment of Islam. ${ }^{16}$ According to the Court, "[b]ecause pedophilia was behavio[[r which was ostracized by society and outlawed," 17 it felt E.S.'s statements violated Austria's Criminal Code by "[p]resenting objects of religious worship in a provocative way capable of hurting the feelings of the followers of that religion could be conceived as a malicious violation of the spirit of tolerance," a spirit which the Court viewed as one of the bases of a wellfunctioning democratic society. ${ }^{18}$

Furthermore, the Court took into account that the seminars were open to the general public when considering the propriety of the sanctions. It concluded that "because of the public nature of the seminars, which had not been limited to members of the Freedom Party, it was conceivable that at least some of the participants might have been disturbed by the statements." 19

Ultimately E.S. was convicted of disparaging religious doctrines, and the Court determined that the "applicant had not intended to approach the topic in an objective manner, but had directly aimed to

11. ItE.

12. STRAFGESETZBUCH [STGB] [PENAL CODE] § 188, https://www.ris.bka.gv.at/ Dokumente/BgblPdf/1974_60_0/1974_60_0.pdf (Austria).

13. See W. Montgomery Watt, MUHAMMAD: Prophet AND Statesman 102 (1961).

14. See E.S., Eur. Ct. H.R. at 4-5.

15. Id. at 4 .

16. See id. at 6 .

17. Id. at 4 .

18. Id. at 4-5.

19. ICt. at 4 . 
degrade Muhammad." 20 The Court issued E.S. a fine of 480 Euros; if she failed to pay, she would receive 60 days incarceration. ${ }^{21}$

To support its reasoning, the Court noted that "child marriages were not the same as pedophilia, and were not only a phenomenon of Islam," but also very common among much of the European monarchy. ${ }^{22}$ By taking Muhammad's marital relationships out of the historical context in which they occurred, the Court perceived that the real purpose behind E.S.'s comments was to incite prejudice. ${ }^{23}$ Along with this historical fact, the Court addressed that while the freedom of religion as protected by Article 9 of the Convention did not allow one to be free from religious criticism, the manner in which religious views are attacked "could engage the State's responsibility in order to guarantee the peaceful exercise of the rights under Article 9." 24 Under this framework, the Court maintained that the statements made by E.S. in her lectures were a threat to the peaceful exercise of Islam in Austria and furthered prejudicial beliefs about Muslims, which warranted sanctioning. ${ }^{25}$

\section{Appellate and Supreme Court Rulings}

E.S. subsequently appealed her conviction to the ECtHR and again argued that the statements were statements of fact, not value judgments, and that she had not intended to disparage Muhammad but was merely "criticiz[ing] the notion that an adult had had sexual intercourse with a nine-year-old . . . [and questioned] whether this ... [was] paedophilia." 26 E.S. further claimed that her statements were covered by her rights under Article 10, which reads as follows:

1. Everyone has the right to freedom of expression. This right shall include freedom to hold opinions and to receive and impart information and ideas without interference by public authority and regardless of frontiers. This Article shall not prevent States from requiring the licensing of broadcasting, television or cinema enterprises.

20. Id. at 4-5.

21. Id. at $2-3$.

22. Id. at 5 .

23. See id.

24. Id.

25. Id.

26. Id. 
2. The exercise of these freedoms, since it carries with it duties and responsibilities, may be subject to such formalities, conditions, restrictions or penalties as are prescribed by law and are necessary in a democratic society, in the interests of national security, territorial integrity or public safety ....27

Based on the tenets above, E.S. asserted that her rights under this article "included the right to impart opinions and ideas that offend[], shock[ or disturb[" and therefore her statements were protected. ${ }^{28}$ While this is true of Article 10, the Court noted the caveat that, while one has the right to impart shocking and disturbing opinions, there is a fine line between shocking speech and that which "seek[s] to spread, incite or justify hatred based on intolerance, including religious intolerance." 29 The Court determined that such statements "do not enjoy the protection afforded by Article 10 of the Convention." 30

E.S. further claimed in her appeal that her statements in the context of these seminars should be viewed as objective criticisms of religion, contributing to public debate-not statements aimed at defaming the Prophet or spurring religious intolerance. ${ }^{31}$ The Court of Appeals did not find this argument persuasive. The Court felt it was evident that "the permissible limits were exceeded where criticism ended and insults or mockery of a religious belief or person of worship . . . began;" 32 and that "even if the applicant had had the right to critici[z]e others' attempts to imitate Muhammad, her statements showed her intention to unnecessarily disparage and deride Muslims." 33 The Court of Appeals thus upheld her conviction. ${ }^{34}$ The Supreme Court affirmed, as it considered that E.S. had not intended to contribute to a serious debate about Islam or the issue of child marriage, but had instead aimed "to defame Muhammad by accusing him of a specific sexual preference, based on the assumption that he had had sexual intercourse with a prepubescent child, in order to show that he was not a worthy subject of worship."35

27. Convention for the Protection of Human Rights and Fundamental Freedoms as Amended by Protocols Nos. 11 and 14, supra note 2, art. 10.

28. E.S., Eur. Ct. H.R. at 5.

29. Id. at 16 .

30. $I d$.

31. See id. at 5.

32. Id. at 6.

33. Id.

34. $I d$.

35. Id. at 7 . 


\section{European Court of Human Rights' Decision}

After losing her appeal to the Austrian Supreme Court, E.S. petitioned the ECtHR ${ }^{36}$ to take her case, hoping that the ECtHR would not only reverse her conviction but also hold that this section of the Austrian Criminal Code punishing the disparagement of religious doctrines was a "violation of Article 10 of the Convention of Human Rights." ${ }^{37}$ It is important to note that the Human Rights Council, which is comprised of the parties to the Convention, has stated in its view on free expression:

Criminal sanctions are only appropriate in respect to incitement to hatred ... there is a high symbolic value in the pan-European introduction of criminal sanctions against incitement to hatred. It gives strong signals to all parts of society and to all societies that an effective democracy cannot bear behavio $\prod r s$ and acts which undermine its core values: pluralism, tolerance, respect for human rights and non-discrimination. It is essential however that the application of legislation against incitement to hatred be done in a non-discriminatory manner. ${ }^{38}$

E.S. argued to the ECtHR that Austria's code was an impermissible infringement of her right to free expression, as she felt that her statements were protected under Article 10, which includes "the freedom to hold opinions and to receive and impart information and ideas without interference by public authority." 39 In asserting that her conviction for the previously mentioned statements was an unlawful

36. See, e.g., John G. Merrils, European Court of Human Rights, ENCYCLOPEDIA BRITANNICA, https://www.britannica.com/topic/European-Court-of-Human-Rights (last updated Mar. 14, 2016)

("European Court of Human Rights (ECtHR), judicial organ established in 1959 that is charged with supervising the enforcement of the Convention for the Protection of Human Rights and Fundamental Freedoms ... [t] the convention obligates signatories to guarantee various civil and political freedoms, including the freedom of expression and religion and the right to a fair trial.").

37. See E.S., Eur. Ct. H.R. at 12.

38. Eur. Comm'n for Democracy Through L. ("Venice Commission"), Report on the Relationship Between Freedom of Expression and Freedom of Religion: The Issue of Regulation and Prosecution of Blasphemy, Religious Insult and Incitement to Religious Hatred, (CDL-AD)(2008)026, ๆ $90-91$ (Oct. 23, 2008).

39. Convention for the Protection of Human Rights and Fundamental Freedoms as Amended by Protocols Nos. 11 and 14, supra note 2, art. 10. 
interference on her right to freedom of expression, she attested that the domestic courts "failed to address the substance of the impugned statements." 40 E.S. argued that because the information she relayed was linked to at least some factual basis, the statements were not mere value judgments and therefore did not exceed the permissible limits of free expression under Article 10.41

Despite these contentions, the ECtHR determined that the lower courts had comprehensively addressed the substance of the impugned statements and concluded that they had not been a part of an objective discussion concerning Islam or the issues of child marriage. They concluded that the statement had been aimed at defaming Muhammad and therefore had "been capable of arousing justified indignation." 42

In rebutting E.S.'s claim that statements such as the ones made in her seminars were necessary for rich public debate, the Court explained that it was not enough to merely "pack incriminating statements into the wrapping of an otherwise acceptable expression of opinion and deduce that this would render the statements exceeding the permissible limits of freedom of expression passable." 43 This is contrary to the appellant's argument that some individual statements, no matter how troublesome, had to be tolerated during a lively discussion. ${ }^{44}$ Sneaking inciting language into an otherwise innocuous setting to perpetuate potential negative perceptions of a religious group as a whole did not, in the Court's view, contribute to public discussion and debate. ${ }^{45}$

The ECtHR also endorsed the domestic court's method of taking other factors into consideration besides the statements themselves, such as the wider context in which the statements were made, stating that "[i]n conclusion, the Court finds that in the instant case the domestic courts comprehensively assessed the wider context of the applicant's statements, and carefully balanced her right to freedom of expression with the rights of others to have their religious feelings protected and to have religious peace preserved in Austrian society." 46

Given these reasons, the ECtHR decided that the lower courts had legitimately "put forward relevant and sufficient reasons and [the Court] finds that the interference with the applicant's rights under Article 10 did indeed corresponded to a pressing social need and was

\footnotetext{
40. E.S., Eur. Ct. H.R. at 12 .

41. See id.

42. Id. at 18-19.

43. Id at 19 .

44. See id.

45. Id.

46. Id. at 20 .
} 
proportionate to the legitimate aim pursued." 47 The domestic courts had a much better understanding of the current state of Austrian society and found that E.S's statements posed potential social harms. Therefore, the Court felt inclined to support the lower courts' determination that intervention was warranted, concluding that there had been "no violation of Article 10 of the Convention." 48

\section{ANALYSIS OF THE EUROPEAN COURT ON HUMAN RIGHTS' REASONING}

It is important to note the structure of Article 10 (Freedom of Expression) to understand the ECtHR's analysis of this case. Under the Convention, free expression does not come free of responsibilities. ${ }^{49}$ Freedom of expression under Article 10 differs from the American First Amendment. The American First Amendment asserts the right to free speech in absolute, stating "Congress shall make no law respecting an establishment of religion or prohibiting the free practice thereof; or abridging the freedom of speech." 50 Under Article 10, one must recognize and abide by the idea that freedom of expression comes with the duty of acting to maintain a peaceful society. ${ }^{51}$ Thus, if speech is found to interfere with this aim by encouraging violence or disrupting peace between citizens, it may warrant regulation. ${ }^{52}$

It should also be observed that Article 9 (Freedom of Thought, Conscience, Religion $)^{53}$ protects the free practice of religion but, as noted in the previous section, does not prohibit one's right to criticize a religion or share an opinion on religious ideals. ${ }^{54}$ Interestingly, both of these articles provide a safeguard for protecting the values of a democratic society, such as religious tolerance, by allowing the State to intervene when speech may serve to impede the democratic aims of the Convention. ${ }^{55}$ Therefore, in cases like the one at hand, courts take the approach of balancing the conflicting rights involved where there seems to be a tension between the ideals of free expression and the free practice of religion. ${ }^{56}$

47. Id.

48. $I d$.

49. See Convention for the Protection of Human Rights and Fundamental Freedoms as Amended by Protocols Nos. 11 and 14, supra note 2, art. 10.

50. U.S. CONST. amend. I.

51. See E.S., Eur. Ct. H.R. at 15.

52. See id. at 15-16.

53. See Convention for the Protection of Human Rights and Fundamental Freedoms As Amended by Protocols Nos. 11 and 14, supra note 2, art. 9 .

54. See E.S., Eur. Ct. H.R. at 15.

55. See id. at 4-5.

56. See id. at 16-17. 
In balancing the rights enshrined in Article 9 and those of Article 10, the ECtHR held in E.S., that E.S.'s freedom of expression did not prevail over the right of Austrian citizens to be free to practice their religion. ${ }^{57}$ The Court determined that E.S.'s speech perverted the aims of tolerance that the ECtHR recognizes as necessary for a well working democracy, because it found that her statements were likely to increase prejudice towards a religious group, which would likely incite hatred, and such hate would likely impede the free practice of Islam in Austria. ${ }^{58}$ Based off of this analysis, one can infer that guaranteeing the safety of citizens to practice their religion and maintaining peace among citizens of different backgrounds was a more pressing concern than ensuring E.S.'s right to express prejudicial views. ${ }^{59}$ This is evidenced in the statement, "a state may therefore legitimately consider it necessary to take measures aimed at repressing certain forms of conduct, including the imparting of information and ideas judged incompatible with respect for the freedom of thought, conscience and religion of others." 60

To help determine the proper balance between these conflicting rights, the Court emphasized both the importance of the context and the intent behind E.S.'s statements. ${ }^{61}$ In looking at the intent behind the statements, the Court made the important determination that there was no other possible objective behind such degradation of an important Islamic religious figure than to encourage prejudicial sentiments towards the religion's followers, regardless of the supposed veracity of the statements. The ability for a court to make this difficult determination of what speech constitutes debate and what speech is actually likely to incite hate and violence has been a prevailing concern among free speech theorists who argue such line-drawing only invites subjectivity and cannot be done without great risk of error, leading to the censoring of much speech that is not in fact hateful. This contention will be discussed later at greater length.

To make this difficult determination between hateful speech and that of public discourse, it is likely that the ECtHR accounted for the context in which these statements were made, in a time of rising animosity toward the Muslim faith across the globe. ${ }^{62}$ This aspect is an

57. See id. at 19 .

58. Id.

59. See id. at 19.

60. Id. at 16.

61. See id. at 18.

62. See, e.g, Christine Ogan et al., The Rise of Anti-Muslim Prejudice: Media and Islamophobia in Europe and the United States, 76 INT'L. COMM. GAZETTE 27, 27-46 (2014) (describing a study detailing the global rise in Islamophobia); Jenna Johnson \& Abigail Hauslohner, 'I Think Islam Hates Us': A Timeline of Trump's Comments About Islam and 
important inference from the Court's basis for their decision as no form of expression exists in a vacuum, and it is impossible to determine whether statements would interfere with a peaceful democracy without taking into consideration the aims the statements are attempting to achieve regarding the location, time period, and current climate in which they are made. ${ }^{63}$ In upholding E.S.'s conviction, the Court seems to be aware of the fact that speech has incredible power to turn ideas into action and prejudicial views can be a harm to society as they can lead to hate-based actions. ${ }^{64}$ This position is evidenced in the European Council's statement that:

Incidents of religious intolerance, discrimination and related violence, as well as of negative stereotyping of individuals on the basis of religion or belief, continue to rise around the world, and [the Council] condemns, in this context, any advocacy of religious hatred against individuals that constitutes incitement to discrimination, hostility or violence, and urges States to take effective measures, as set forth in the present resolution, consistent with their obligations under international human rights law, to address and combat such incidents. ${ }^{65}$

In this light, the ECtHR's decision in E.S. and the minimal sanctions involved (a relatively small fine of 480 euros) can thus be viewed as an important symbolic posture for the countries party to the Convention, as well as other nations that provide for free expression: prejudicial views will not be tolerated. Such a stance is necessary to address the ubiquitous issue of hate-motivated violence. ${ }^{66}$

Muslims, WASH. POST (May 20, 2017), https://www.washingtonpost.com/news/postpolitics/wp/2017/05/20/i-think-islam-hates-us-a-timeline-of-trumps-comments-about-islamand-muslims/?noredirect $=$ on\&utm_term $=.6983 \mathrm{f} 31 \mathrm{c} 12 \mathrm{de}$; Reuters, Religious Conflict in Global Rise, TELEGRAPH (Jan. 14, 2014, 6:50 PM), https://www.telegraph.co.uk /news/worldnews/middleeast/10572342/Religious-conflict-in-global-rise-report.html.

63. See E.S., Eur. Ct. H.R. at 18 ("The Court notes at the outset that the subject matter of the instant case is of a particularly sensitive nature, and that the (potential) effects of the impugned statements depend, to a certain degree on the situation in the country where the statements were made at the time and the context in which they were made.").

64. See The Psychology of Hate Crimes, AM. PsychoL. Ass'N, https://www.apa.org/advocacy/interpersonal-violence/hate-crimes (last visited Jan. 1 , 2018) ("Hate crimes are an extreme form of prejudice ... [p]ublic and political discourse may devalue members of unfamiliar groups ... [this] can lead to dehunanization of unfamiliar groups and to targeted aggression.").

65. E.S., Eur. Ct. H.R. at 10.

66. See id. at 8. 


\section{CRITICISMS OF THE E.S. RULING}

Despite the potential positive aims behind the ECtHR's ruling in E.S., this decision was not met without controversy. ${ }^{67}$ A writer for The Atlantic stated his view that the decision was actually a result of an "inability of some Muslim's to handle polemics against their religion with grace." 68 The article conveys the general tone that this writer viewed E.S's statements as nothing more than criticism that did not have any potential negative effects aside from possibly hurting some feelings. ${ }^{69}$ To this writer, E.S. was just "repeating" the historical claims against Muhammad, and this ruling represented a "bad sign for the civil liberties in Europe."70

Notably, the author did not indicate that E.S. was not only recounting the historical fact that Muhammad had a young wife, but also adding her own influence as well. ${ }^{71}$ Further, by only looking at the statements as religious criticism, the author seems to belittle the potential impact they may have on furthering prejudice..$^{72}$ Therefore, it is useful to note that many studies have shown that "[d]angerous speech-hate speech that has the potential to influence people to accept, condone, or commit violence against targeted groups-is consequently considered both a warning sign and an instrument of group-targeted violence. ${ }^{73}$ Additionally, to indicate that prejudicial effects are far from insignificant, a recent study from the United Kingdom showed that hate crimes linked to religion had doubled in the last three years in the

67. See, e.g., Shane Armstrong, The Case of E.S. v. Austria: What It Means for the Rights of Europeans, LIBERALIST INT'L ASS'N (Nov. 3, 2018), https://liberalistia.com/theember/es-v-austria-echr-ruling-03-11-2018; Simon Cottee, A Flawed European Ruling on Free Speech, ATLANTIC (Oct. 31, 2018), https:/www.theatlantic.com/ideas /archive/2018/10/e urope-rules-against-free-speech/574369/; Frank Cranmer, Freedom of Expression or Criminal Blasphemy?: ES v Austria, L. \& Religion U.K. (Oct. 26, 2018), https://www.lawandreligionuk.com/2018/10/26/freedom-of-expression-or-criminal-

blasphemy-es-v-austria;; Can Yeginsu \& John Williams, Criminalizing Speech to Protect Religious Peace? The ECtHR Ruling in E.S. v. Austria, JUST SECURITY (Nov. 28, 2018), https://www.justsecurity.org/61642/criminalizing-speech-protect-religious-peace-ecthrruling-e-s-v-austria/.

68. Graeme Wood, In Europe, Speech Is an Alienable Right, ATLANTIC (Oct. 27, 2018), https://www.theatlantic.com/rdeas/archive/2018/10/its-not-free-speech-criticize-

muhammad-echr-ruled/574174/.

69. See id.

70. $I d$.

71. See id.

72. See id.

73. Rachel Brown, Defusing Hate: A Strategic Communication Guide to Counteract Dangerous Speech, U.S. HOLOCAUST MEMORLAL MUSEUM, https:/www.ushmm.org/ confront-genocide/how-to-prevent-genocide/hate-speech-and-incitement-to-genocide/ defusing-hate-a-guride-to-comteract-dangerous-speech (last updated 2016). 
United Kingdom, and that the Muslim community was the most commonly targeted group, followed by members of the Jewish community. ${ }^{74}$ With this information in mind, one can start to see that statements that further prejudice, especially against an already marginalized groups, should not be ignored.

Another point of contention against this ruling is evidenced by an unenthused journalist who stated that this ruling "should strike fear into the parents of Europe" as he felt that the ruling punished E.S. for her opinions, not for inciting hatred. ${ }^{75}$ This is evidenced by his statement "that [the view that Muhammad was a pedophile] was E.S.'s opinion, just as it was Voltaire's opinion that Christianity is an 'infamy' that must be 'erased' and just as it was Nietzsche's opinion that Jesus is not a worthy subject of worship." 76

This writer's argument does add some color to this debate, as Article 10 and other free speech regimes typically do protect the ability for one to share one's opinions. ${ }^{77}$ Although the author is persuasive with his examples, one can differentiate E.S. from Voltaire and Nietzsche in this instance. Rather than merely expressing an opinion, E.S. was teaching a course, "Basic Information on Islam," and therefore was an instructor possessing a role of authority and credibility in the eyes of her participants, which could make her statements more likely to be perceived as truisms rather than opinions. Moreover, if the participants were not already knowledgeable on the subject matter, or already reserved biases towards Muslims, E.S.'s statements would not necessarily be understood within a context of simple opinion.

Under the Convention, one does have the right to share their opinions, ${ }^{78}$ but the permissible limits of that right come into question when one abuses that right to perpetuate prejudicial opinions under the

74. Ashley Kirk, Hate Crime Linked to Religion Doubled in Three Years, TELEGRAPH (Oct. 16, 2018, 11:29 AM), https://www.telegraph.co.uk/news/2018/10/16/hate-crimelinked-religion-doubled-three-years/.

75. Dominic Green, Europe's Dangerous Blasphemy Laws Are Ripe for Exploitation, WKLY. STANDARD (Nov. 5, 2018, 2:55 AM), https://www.weeklystandard.com/dominicgreen/european-court-blasphemy-free-speech-isnt-what-it-used-to-be.

76. See id.

77. See Convention for the Protection of Human Rights and Fundamental Freedoms as Amended by Protocols Nos. 11 and 14, supra note 2, art. 10. See generally Richard Wike \& Katie Simmons, Global Support for Principle of Free Expression, but Opposition to Some Forms of Speech, PEW RES. CTR. (Nov. 18, 2015), http://www.pewglobal.org /2015/11/18/global-support-for-principle-of-free-expression-but-opposition-to-some-formsof-speech/ (summarizing results of a study holding that "nearly all 38 nations polled say it is at least somewhat important to live in a country with free speech, a free press and freedom on the internet").

78. See STEVEN GREER, THE EXCEPTIONS TO ARTICLES 8 TO 11 of the EUROPEAN CONVENTION ON HUMAN RIGHTS 38 (1997). 
guise of education. To further indicate the dangers posed by prejudicial statements, sociologist Milton Kleg asserts that "the sources of prejudice are varied. But regardless of how and why prejudices form, the fact remains that, like seeds, prejudice takes root, grows, and blossoms into what may become violent hate." 79 Given the mushrooming effect that prejudice seems to have, it is unsurprising that some legal theorists are actually in favor of sanctions like the ones in this case, supporting the view that "[c]ounteracting prejudice's] dissemination provides us with one avenue of preventing this type of violence from occurring." 80

Interestingly, this author's greatest issue was not with the ECtHR's analysis, which he did acknowledge accurately followed the applicable laws at issue, but with the fact that such a law (prohibiting the disparagement of religious doctrines) was permitted in the first place. ${ }^{81}$ This is evidenced in his statement: "[i]f [disparaging religious figures] is a crime- and in Austria it is- then she is guilty, and it falls to the people of Austria to revise their laws to protect her rights, and theirs." 82 While the author may perceive that laws against blasphemous speech are unduly intrusive on individuals' rights to free expression, Austria is not an outlier. In 2017, one in three countries were reported to have criminal sanctions for blasphemous speech like that at issue in the case of E.S. ${ }^{83}$

Another argument this author had against the holding of this case was that the ECtHR was not valuing free expression enough. Instead, the author argues, Austria should be more like America when it comes to free speech, stating that "the American system of virtually limitless debate has proved highly capable of discrediting Irving (holocaust denier), and of allowing Islamophobes and Islamists to yap at each other. It blames violence on the violent." 84

The issue with this argument is that the author seems to see absolutely no value to be had in restricting some types of speech, or that any forms of sanctions on speech may be necessary to maintain an orderly society. Such a blasé view seems a direct affront to popular psychological studies of prejudice like that of Gordon W. Allport, who concluded that "prolonged and intense verbal hostility always precedes

79. Alexander Tsesis, Dignity and Speech: The Regulation of Hate Speech in a Democracy, 44 WAKE FOREST L. REV. 497, 520 (2009).

80. Brown, supra note 72.

81. See Wood, supra note 67.

82. Id.

83. Stephanie Nebehay, Blasphemy Laws: One-in-Three Countries Still Criminalise Anti-Religious Sentiment, Study Finds, INDEPENDENT (Aug. 29, 2017, 9:51 AM), https://www.independent.co.uk/news/world/blasphemy-laws-countires-islamic-pakistanyemen-anti-religious-sentiment-illegal-criminalise-freedom-a7917611.html.

84. Wood, supra note 67. 
a riot"" 85 and "historical evidence [indicates] that hate speech is critical to the perpetration of violence." 86

The issue of this author's over idealization of the American system of free expression is that it fails to note how America has seen its fair share of hate influenced violence, ${ }^{87}$ and the issue with the over idealization of an "anything goes, free market place of ideas" model for free expression will be further discussed.

Another popular argument regarding the outcome of this case is the fear among some in the Muslim community that the ruling would seem to be "playing favorites for those of the Muslim faith, and actually 'serve to stoke Islamophobia, rather than promote integration." 88 This is unfortunately one of the most persuasive arguments against sanctioning speech like that in the case of E.S.; the persuasive effect comes not from the rights of the speaker being silenced but more from fear of retaliation to those who are being protected by such sanctions. It is hard to think of a way to address this potential side effect of speech regulation beyond trying to promote tolerance, such as making special efforts to properly educate citizens on the values of a diverse society as well as debunking popular misconceptions and stereotypes of different races and religions. ${ }^{89}$ If we make such efforts, hopefully individuals will not grow to resent speech regulations that protect their fellow citizens, but rather see regulation simply as part of the cost of ensuring peace in a democratic nation, an aim that benefits everyone.

\section{FOUNDATIONAL THEORIES OF FREE EXPRESSION: REALISTIC IN TODAY'S SOCIETY?}

What many of these arguments against this ruling have in common is that they appear to rely on certain classic theories of free expression to support their contention that this ruling is an affront to free

85. Tsesis, supra note 78 , at 514 (quoting GORDON W. ALLPORT, THE NATURE OF PREJUDICE 60 (1979)).

86. $I d$. at 516 .

87. See, e.g., HowARD J. EHRLICH, HATE CRIMES AND ETHNOVIOLENCE: THE HistoRY, CURRENT AFFAIRS, AND FUTURE OF DISCRIMINATION IN AMERICA (2009); MICHAEL NEWTON \& JUDY ANN NEWTON, RACIAL \& RELIGIOUS VIOLENCE IN AMERICA: A CHRONOLOGY (1991); Maritza Perez, From Rhetoric to Racial Violence: Hate Crimes Against Latinos in America, Then and Now, 43 AZTLAN 151 (2018).

88. Mustafa Akyol, The Prophet Mohammad Doesn't Need Courts to Protect Him, CATO INST. (Nov. 1, 2018), https://www.cato.org/publications/commentary/prophetmohammed-doesnt-need-courts-protect-him.

89. See, e.g., Calvin K. Lai et al., Reducing Implicit Prejudice, 7 Soc. Personality PSYCHOL. COMPASS 315 (2013) (describing methods for influencing implicit prejudice and potential solutions to implicit prejudice). 
expression. One of the most prevailing of these free expression theories is that expression should never be censored or regulated, as it is expression that helps one reach their true potential as an individual and helps society find "truth." 90 The idea that unlimited expression can always lead to truth is personified by the famous quote by philosopher Alexander Meiklejohn, "[f]reedom is always wise."91 This stance is further embodied by the work of Thomas Emerson, who was of the position that "the process of conscious thought ... can have no limits." 92 To Emerson, any form of restraint over expression is "the greatest displeasure and indignity to a free and knowing spirit that can be put upon him." 93

According to Emerson and other theorists in this camp, it is only through expression that individuals can find truth, and while "full discussion, open to all, involves some risks to the society that practices it," these risks are worth taking, as eventually the accumulation of all expressions will lead to the greater truth. ${ }^{94}$ Therefore, many of the criticisms of the E.S. ruling can be inferred to be motivated by such a stance, that the regulation of religiously insensitive speech impedes the search for truth and hurts individual autonomy. That being said, the regulation of speech like that in the case of E.S. is not in complete conflict with this idea, as the "[r]egulation of objectively false information conforms with free speech theory .... False information does not add to our knowledge. ${ }{ }^{95}$ By removing from society speech that is patently false, or serves to support illegitimate stereotypes, the aims of free expression in reaching greater truth are not being stifled, but nurtured.

Another flaw in Emerson's theory is that it relies on the argument that "open discussion . . . that lead[s] to greater cohesion" and that by "allowing dissidents to expound their views [it] enables them 'to let off steam," which will result in a release of energy, avoiding any threats to law and order. ${ }^{96}$ This view of a sort of "safety valve" theory for free expression foolishly relies on the presumption that allowing freedom of expression in all forms will serve as an outlet to avoid violence. The

90. See, e.g., Thomas I. Emerson, Toward a General Theory of the First Amendment, 72 YALE L.J. 877, 879 (1963).

91. AleXANDER MEIKLEJOHN, The Congress and the People, in Political FREEDOM: The CONSTITUTIONAL POWERS OF THE PEOPLE 112 (F960).

92. Emerson, supra note 89, at 879.

93. Id. at 880 (quoting JOHN MUTON, AREOPAGITICA 21 (Everyman's Library ed. 1927) (1644)).

94. Id. at 886 .

95. Edward J. Eberle, Practical Reasan: The Commercial Speech Paradigm, 42 CASE W.

RES. L. REV. 411, 483 (1992).

96. Emerson, supra note 89 , at 885 . 
shortsightedness of this theory lies in the fact that it fails to note how a greater accumulation of negative views can actually be used to enforce prejudices and lead to violence, as opposed to trying to avoid it.97 Further, this theory is limited by time. Emerson himself noted that at "times there may be substantial delay in the working out of critical problems." 98 The issue here is that in a society with increasing violence, there may not be the time to wait for such "working out."

The dissenters against the E.S. opinion also appear to rely on the theory of free expression, as a sort of "marketplace of ideas." 99 This theory "explains the importance of freedom of speech in terms of an open 'marketplace' in which ideas are allowed to compete against one another in an ongoing process of human enlightenment." 100 Similar to Emerson's theory, this theory relies on the thought that what is "right" or "true" will eventually reign as the expressions that are "wrong" or "false" will be exposed for what they are when subjected to the marketplace. ${ }^{101}$

While this may work in theory, in an increasingly polarized society where individuals become further reliant on information that already conforms to their own worldviews, it is unlikely that one's expressions will be subject to the rigorous debate needed for this theory to hold true. ${ }^{102}$ One journalist contributed her view of the flaws of this theory by stating that "whatever its merits, the European position is rooted in its experiences that the free market of ideas can fail-disastrously. Dangerous ideas can catch on quickly, especially when people holding power or influence endorse them." 103 As E.S. was an individual with

97. See generally Wiktor Soral et al., Exposure to Hate Speech Increases Prejudice Through Desensitization, 44 AGGRESSIVE BEHAV. 136 (2018) (explaining research showing that consistent exposure to hate speech increases desensitization and prejudice); Rachel Hatzipanagos, How Online Hate Turns into Real Life Violence, WASH. POST (Nov. 30, 2018), https://www.washingtonpost.com/nation/2018/11/30/how-online-hate-speech-isfueling-real-life-violence/?noredirect=on\&utm_term=.6122d0ee6276 (relating whitesupremacist online hate speech to violence).

98. Emerson, supra note 89, at 886.

99. RodNey A. Smolla, SMolla \& Nimmer on Freedom of Speech § 2:4, Westlaw (database updated April 2019).

100. Id.

101. See id.

102. See, e.g., CATHERINE A. MACKInNON, ONLY WoRDS 69-110 (1993); David Robert Grimes, Echo Chambers are Dangerous - We Must Try to Break Free of Our Online Bubbles, GUARDIAN (Dec. 4, 2017, 6:27 AM), https://www.theguardian.com/ science/blog/2017/dec/04/echo-chambers-are-dangerous-we-must-try-to-break-free-of-ouronline-bubbles.

103. Mila Versteeg, What Europe Can Teach America About Free Speech, ATLANTIC (Aug. 19, 2017), https://www.theatlantic.com/politics/archive/2017/08/what-europe-canteach-america-about-free-speech/537186/. 
influence over her participants, it is likely that her ideas regarding the Prophet could have "caught on" quickly, and without the lively marketplace that Emerson envisions, it is hard to tell whether such comments would actually be exposed for what they are in the absence of intervention.

Another main aspect of Emerson's theory which dissenters of the E.S. opinion may be relying on is the view that only action should be regulated by the State, as opposed to expression. ${ }^{104}$ According to Emerson, "[e]xpression in itself is not normally harmful, and the objective of limitation is not normally to suppress the communication as such. Those who seek to impose limitation on expression do so ordinarily in order to forestall some anticipated effect of expression in causing or influencing other conduct." ${ }^{105}$ The issue here is that Emerson fails to see how expression can lead to harm, while advocating a problematic handsoff approach of the State until such harmful conduct occurs. ${ }^{106}$ Such a stance seems somewhat nonsensical, as the State should not stand idly by and wait until something horrible happens to intervene, as opposed to being proactive and stopping dangerous forms of expression before they precipitate inevitably into violence. By treating expression and conduct as two disparate entities, Emerson's theories fail to see how they are in fact intimately related and have great influence over one another. ${ }^{107}$

Another aspect of first amendment theory that critics of the E.S. decision seem to hold on to is the fear of government overregulation and the prevailing argument that it is too difficult for governments to make such distinctions without being subjective in determining what speech is problematic and violent, and what is necessary for public debate. ${ }^{108}$ Rebutting this contention, however, Mari Matsuda asserts that "we are capable of discernment, of telling a cross burner from an antiwar protestor.... If definition of harmful speech is impossible, we are doing the impossible as we define slander [and] fraud." 109 To Matsuda this distinction is not a hard one to make, as logical individuals are capable of telling the difference between hateful speech and that of protest, and

104. See Emerson, supra note 89 , at 889 .

105. Id.

106. See id.

107. See generally Soral, supra note 96, at 144 (finding that exposure to hate speech increases desensitization to such speech and "increase[s] outgroup prejudice expressed toward the victims of those hostile statements").

108. See, e.g., Emerson, supra note 89, at 889-92.

109. MARI J. MATSUDA, Progressive Civil Liberties, in WHERE IS YOUR BODY? 131, 136-40 (1996). 
the law has been drawing these fine distinctions in other areas for decades. ${ }^{110}$

According to Matsuda, "we do not have to let crosses burn, because they are not about debating race relation[s]--they are about punishing, silencing, and running families out of their homes."111 This argument indicates how Matsuda relies heavily on the importance of context in the free expression debate. 112 Matsuda explains that "[w]e cannot pretend not to know who is screaming what, to whom, in what context, and with what result." 113 In noting the importance of context, and marking her stance against unrestricted freedom of expression, Matsuda maintains that "[a]bsolutism is a luxury, the luxury of not asking to whom, to what end, in what historical context, and with what present politics." 114

To Matsuda, regulations on speech may actually be a way to ensure that everyone's rights, including the right to free expression, are protected.115 Noting the counterintuitive nature of such a theory Matsuda explains that "[t]his is indeed a paradox-no easy walk to freedom, no easy civil liberties." 116 Thus, the dissenters of the E.S. decision can be said to not recognize the historical time in which such statements are being made, a time with rising animosities towards the Muslim faith. ${ }^{117}$ Furthermore, they fail to see how ensuring the ability of their fellow citizens to feel safe in practicing their religion benefits the rights of everyone as well.

\section{CONCLUSION}

In light of recent acts of hate occurring around the world, such as the mass shooting of a synagogue in Pittsburgh by a man who frequently espoused anti-Semitic views online, which resulted in the

110. See id. at 136 .

111. Id. at 142 .

112. See id.

113. Id. at 138 .

114. Id. at 144 .

115. See id. at 143 .

116. Id.

117. See, e.g., Lizzie Dearden, Street Attacks on Muslims Rocket in UK as Perpetrators 'Emboldened' by Terror Attacks and Political Rhetoric, Report Finds, INDEPENDENT (Jul. 23, 2018, 12:03 AM), https:/www.independent.co.uk/news/uk/home-news/attacksmuslims-uk-terror-islam-hate-crime-brexit-tell-mama-a8457996.html; Katayoun Kishi, Assaults Against Muslims in U.S. Surpass 2001 Level, PEW RES. CTR. (Nov. 15, 2017), http://www.pewresearch.org/fact-tank/2017/11/15/assaults-against-muslims-in-u-ssurpass-2001-level/. 
death of eleven; 118 the shooting of a mosque in Quebec which resulted in the death of six; ${ }^{119}$ and an incident in Germany, where a man motivated by anti-foreigner views intentionally drove off of the road to kill pedestrians, which resulted in the death of four; 120 it has become painfully apparent that something needs to be done to curb hate-based rhetoric before more of these horrific incidents occur. It has become evident that "hate crime flourishes in an enabling environment," 121 and if speech that is intended to incite prejudice and religious animosities is allowed to continue, it will only serve to create the ideal breeding ground for such violence. Unfortunately, it is also becoming increasingly clear that "hate and intolerance do not respect political boundaries and physical borders,"122 allowing for the issue of hate speech to be viewed as an international crisis. Thus, rulings like E.S. $v$. Austria may be necessary to put a stop to where most violent incidents likely begin, with hate-based speech. If we cannot see an increase in rulings like that in this case, then "in an unregulated marketplace of ideas, private citizens need to take up the burden of holding the line against racist extremism." 123 Through legislative bodies or through the judiciary, authorities must take more stringent action to guard against hate speech, as it is having detrimental effects around the world and will continue to do so unless something is changed. That being said, perhaps the $E . S$. ruling can be viewed as a marginal step in the right direction.

118. Campbell Robertson et al., 11 Killed in Synagogue Massacre; Suspect Charged with 29 Counts, N.Y. TIMES (Oct. 27, 2018), https://www.nytimes.com/2018/10/27/us/activeshooter-pittsburgh-synagogue-shooting.html.

119. Dan Bilefsky, Quebec Mosque Shooter Was Consumed by Refugees, Trump and Far Right, N.Y. TIMES (May 5, 2018), https:/www.nytimes.com/2018/05/05/world/canada/ quebec-mosque-attack-alexandre-bissonnette.html.

120. See Associated Press in Berlin, Several People Injured After Man Drives Car into Crowd in Germany, GUARDIAN (Jan 1, 2019, 9:05 AM), https://www.theguardian.com /world/2019/jan/01/man-drives-car-into-crowd-bottrop-germany; Andrea Thomas, German Man Drives Car into Crowd in Apparent Xenophobic Attack, WaLL STREkT J. (Jan. 1, 2019), https://www.wsj-com/articles/four-people-injured-in-possible-xenophobic-attack-ingermany-11546359219.

121. Barbara Perry, Intervening Globally: Confronting Hate Across the World, 27 CRIM. JUST. POL'Y REV. 590, 59I (2016).

122. Amanda Coletta, Hate Crimes in Canada Surge 47\%, Fueled by Attacks on Jewish, Muslim and Black Poputations, WASH. POST (Dec. 4, 2018), https://www. washingtonpost.com/worId/2018/12/04/hate-crimes-canada-surge-fueled-by-attacks-jewishmuslim-black-populations/?utm_term=.d583802b874a.

123. Versteeg, supro note 102. 